\title{
Kierkegaard and Issues in Contemporary Ethics
}

\author{
International Conference
}

\author{
ESC Clermont \\ Clermont-Ferrand, France
}

2-3 May 2019

Periodically brought to the fore in times of social and intellectual upheaval, Kierkegaard's philosophy, and existential philosophy more generally, has often been associated with what Hannah Arendt termed a 'willingness to tear down outmoded intellectual structures,' and a return to the question(s) of the existing human being. More recently, philosophers such as Alasdair MacIntyre and Jürgen Habermas have appealed to Kierkegaard's existential understanding of ethics as a way of moving beyond the sterile debates in normative ethics and of opening up the sphere of moral philosophy through an existential turn. Despite this renewed interest, little work has been done on how Kierkegaard could fruitfully be drawn into contemporary questions in ethics. Although existential philosophy is perhaps best characterized as a philosophy which focuses on 'concrete' existence, it is curious that it has not often enough been challenged with regard to concrete moral issues.

The aim of this conference is to attempt to bring to the fore some of these issues, and engage with them from the perspective(s) of existential ethics. Do Kierkegaard's writings contain resources which could enable us to think through contemporary issues which the Dane himself never envisaged, such as the liberalization of genetic manipulation, acts of terrorism or political violence, the impact of new technologies on personal identity and social interaction, migration, gender identity, poverty and social inequality, the protection of the natural environment, the legalization of euthanasia, or the regulation of artificial intelligence?

From the definition of the individual within the political sphere to the definition of humanity confronted with the increasing technicality of the environment, Kierkegaard's philosophy continues to engage with those issues which shape our modern human condition and the mutations of our contemporary societies.

Paper proposals dealing with Kierkegaard and any issues in contemporary and/or applied ethics are welcome. Abstracts of no more than 500 words should be sent to kierkegaard.clermont@escclermont.fr by 1 December 2018. Notification of acceptance in January 2019.

Organisation: Mélissa Fox-Muraton (melissa.fox-muraton@esc-clermont.fr)

Scientific committee: Karl Verstrynge, René Rosfort, Roe Fremstedal

For all queries, contact: kierkegaard.clermont@esc-clermont.fr

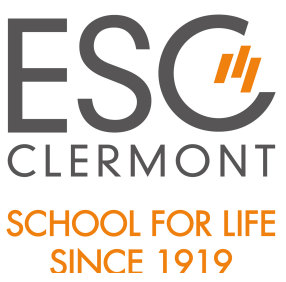

